Wawasan:

Jurnal Kediklatan Balai Diklat Keagamaan Jakarta

PISSN: 2548-9232; EISSN: 2775-3573

Volume 2 Nomor 2 Tahun 2021: 111-120

\title{
FACEBOOK SOLUSI KREATIF MEDIA PARENTING JARAK JAUH DI RAUDHATUL ATHFAL
}

\author{
Robi'ah Ummi Kulsum \\ Balai Diklat Keagamaan Jakarta, Indonesia \\ E-mail:hanna.umm@gmail.com
}

\begin{abstract}
In Raudhatul Athfal the role of the family is still very dominant. In this context, there is an interaction between the family and the teachers. Parenting is a method to build the interaction between them. The purpose of this study was to determine the impact Facebook as a parenting media in Raudhatul Athfal (RA). The research is descriptive qualitative. The results showed that Facebook had not been used effectively as a parenting media at the Raudhatul Athfal. It is recommended to improve quality of activity, utilizing features more properly, improving content and follow-up activities with offline activity.

Keywords: Raudhatul Athfal, parenting, facebook.

Abstrak

Pada proses pendidikan di Raudhatul Athfal peran keluarga masih sangat dominan disbanding dengan tingkat pendidikan berikutnya. Pada konteks ini terjadi interaksi antara keluarga dengan guru. Parenting adalah upaya yang dapat menjembatani interaksi keduanya. Tujuan penelitian ini adalah mengetahui dampak pemanfaatan Facebook sebagai media parenting di Raudhatul Athfal (RA). Penelitian bersifat deskriptif kualitatif. Hasil penelitian menunjukkan bahwa Facebook belum dimanfaatkan sebagai media parenting di lembaga Raudhatul Athfal lakasi penelitian. Direkomendasikan agar optimalisasi pemanfaatan Facebook sebagai media parenting di bisa dilakukan melalui perbaikan pola kegiatan, pemanfaatan fitur, perbaikan konten dan tindak ditambahkan kegiatan tindak lanjut berupa parenting offline.
\end{abstract}

Kata kunci: Raudhatul Athfal, parenting, facebook. 


\section{PENDAHULUAN}

Pembelajaran online (daring) yang menjadi solusi pada masa pandemi Covid-19 ini telah menyebabkan aspek afektif dan psikomotorik tidak tercapai. Hambatan pada aspek afektif atau biasa dikenal sebagai aspek sosial emosional (sosem) pada Pendidikan Anak Usia Dini (PAUD) meliputi hambatan perkembangan sosial dan emosi, sedangkan hambatan psikomotorik meliputi motorik kasar maupun halus. Hambatan dalam perkembangan sosial emosi anak terjadi berupa stress, sensitivitas meningkat, temper-tantrum, manja dan tidak mandiri serta gangguan perilaku (Tabi, 2020), sementara hambatan psikomotorik berupa kurangnya stimulasi motorik kasar dan halus secara signifikan (Nuraini, 2020). Wiresti melaporkan (Wiresti, 2020) terdapat pengaruh tidak langsung Work from Home akibat pandemi Covid-19 terhadap psikologi anak yaitu emosi yang tidak stabil, krisis gizi dan kesehatan anak, terjadinya gap pembelajaran, krisis keamanan dan kenyamanan dan krisis pengasuhan anak. Beberapa aspek indikator pertumbuhan dan perkembangan anak yang seharusnya diobservasi secara berkala, menjadi satu kegagapan dalam pendidikan orang tua di masa pandemi. Kegagapan ini sejalan dengan yang ditunjukkan Sri Anita Rachman (Anita Rahman, 2020) bahwa orang tua anak usia dini meski lebih memilih proses pembelajaran daring, tetapi mereka menyepakati untuk melakukan pendampingan dalam pembelajaran jarak jauh (daring) ini dalam rangka memutuskan mata rantai penyebaran Covid-19. Diperlukan studi parenting dalam mendukung pendampingan ini.

Sejauh ini studi parenting pada pendidikan anak usia dini di masa pandemi cenderung melihat permasalahan secara makro. Kecenderungan dari studi parenting terdahulu yang dapat dipetakan adalah pertama, studi parenting tentang kendala-kendala dalam mendampingi anak belajar di rumah selama masa pandemi (Wardani \& Ayriza, 2020), (Rohayani, 2020), (Ismaniar, Utoyo,Setiyo, 2020); kedua, studi tentang peranan orangtua dalam mendampingi anak di masa pandemi (Kurniati et al., 2020),(Anita Rahman, 2020), (Fransiska, 2020); ketiga, strategi parenting dalam pembelajaran PAUD di masa pandemi (Nirmala \& Annuar, 2020), (Winarti, 2020), (Oktaria \& Putra, 2020) .

Ketiga studi parenting tersebut masih bersifat umum, belum melibatkan pemanfaatan media sosial. Dari beberapa kecenderungan tersebut, nampak belum terdapatnya solusi kreatif dalam parenting di masa pandemi.

Tulisan ini didasarkan pada satu argumen bahwa terjadinya hambatan sosial emosi dan psikomotorik pada pembelajaran daring bagi anak usia dini disebabkan oleh rendahnya pemahaman orangtua terhadap 
pencapaian pertumbuhan dan perkembangan anak usia dini. Latar belakang pendidikan maupun status sosial orang tua mempengaruhi berhasilnya pembelajaran di PAUD (Fransiska, 2020).

Umumnya orang tua berbeda dalam menyikapi beberapa hal dalam pembelajaran AUD, seperti pengembangan kreatifitas anak, upaya meningkatkan kemampuan otak anak melalui gizi dan nutrisi, serta cara optimalisasi potensi anak. Pengetahuan yang terbatas dan kesadaran tentang pentingnya program pencapaian pertumbuhan dan perkembangan anak usia dini menjadi penyebab hambatan sosial emosi dan psikomotorik.

Penelitian ini menindaklanjuti penelitian sebelumnya yang membahas tentang kendala parenting, peranan orang tua dalam pendampingan di masa pandemi dan strategi parenting. Penelitian Agus Winarti (Winarti, 2020) dalam implementasi parenting pada PAUD di masa pandemi Covid-19 menyatakan bahwa fungsi orang tua sebagai pembimbing, pendidik, penjaga, pengembang dan pengawas saat ini adalah (1) secara khusus menjaga dan memastikan anak untuk menerapkan hidup bersih dan sehat, mengikuti protokol kesehatan, (2) melaksanakan pendampingan anak dalam mengerjakan tugas sekolah secara daring, (3) mengerjakan aktivitas bersama selama di rumah, menciptakan lingkungan yang nyaman agar anak betah tinggal di rumah saja,
(5) memastikan faktor pendukung pendidikan anak usia dini masa pandemi Covid-19 serta ketersediaan sarana dan prasarana pendukung untuk daring, dan (6) memelihara komunikasi orang tua dan guru PAUD dengan baik.

Pemerintah dalam hal ini Kementerian Agama telah memfasilitasi pembelajaran daring dengan memberikan kuota bagi para peserta didik termasuk anak-anak RA (Juliyani, 2020).

Kementerian Agama juga telah memberikan acuan regulasi pelaksanaan Parenting di RA dalam SK Dirjen Pendis No. 2769 Tahun 2019 tentang Petunjuk Teknis Pemberdayaan Orang Tua di Raudhatul Athfal.

Berdasarkan paparan di atas dapat dirumuskan permasalahan yaitu:

1. Bagaimana Raudhatul Athfal memanfaatkan Facebook sebagai media parenting?

2. Bagaimana teknik optimalisasi Facebook sebagai media parenting?

\section{METODE}

Penelitian ini memilih media sosial Facebook sebagai media parenting di Raudhatul Athfal karena Facebook adalah media sosial yang paling banyak digunakan oleh guru dan orang tua. Umumnya, pemanfaatan Facebook hanya sekedar pertemanan, berbagi informasi, entrepreneur atau untuk menambah eksistensi diri.

Penelitian bersifat Deskriptif Kualitatif, dengan memanfaatkan data 
Wawasan:

Jurnal Kediklatan Balai Diklat Keagamaan Jakarta PISSN: 2548-9232; EISSN: 2775-3573

Volume 2 Nomor 2 Tahun 2021: 111-120

kualitatif yang dijabarkan secara deskriptif.

Tujuan tulisan ini mengetahui teknik optimalisasi Facebook sebagai media parenting pada lembaga Raudhatul Athfal dalam analisis solusi kreatif parenting sehingga dapat mengedukasi program pencapaian pertumbuhan dan perkembangan anak usia dini di masa pandemik.

Responden dipilih dari alumni peserta pelatihan Tematik RA BDK Jakarta tahun 2018 dan tahun 2019 secara random, dengan alasan responden telah memiliki dasar pengetahuan yang diperoleh dari pelatihan yang diselenggarakan oleh BDK Jakarta sehingga mempermudah proses pemerolehan data.

Proses penelitian dilakukan secara bertahap seperti pada Gambar 1.

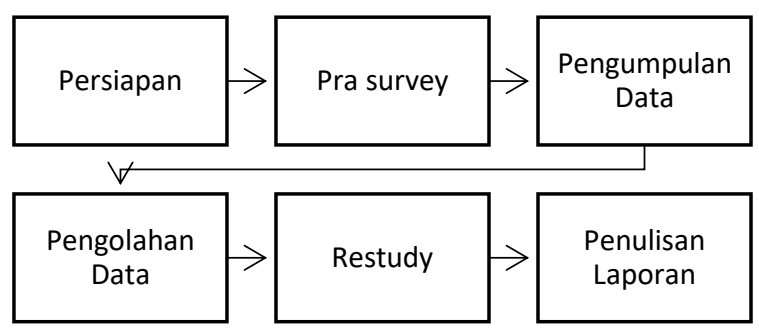

Gambar 1 Alur Penelitian

Teknik pengumpulan data dengan menggunakan wawancara menggunakan Google Form, observasi, zoom meeting, dan chatt Whatsapp.

Dalam menganalisis data dilakukan teknik interpretasi sehingga dapat mengetahui pemanfaatan Facebook sebagai media parenting di RA dan teknik optimalisasinya di Raudhatul Athfal.

\section{HASIL DAN PEMBAHASAN}

Melalui pengumpulan data diperoleh hasil yang menjawab pertanyaan dalam tujuan penelitian sebelumnya.

Pertama, tentang pelaksanaan parenting di Raudhatul Athfal (RA). Terdapat tiga (3) kondisi kegiatan parenting di RA yang berlangsung selama masa pandemi Covid-19 ini terlihat pada Gambar 2: (1) RA melakukan parenting secara terprogram sebanyak 70\%; (2) RA melakukan parenting tapi belum terprogram sebanyak 10\%; dan (3) RA belum melakukan parenting sebanyak $20 \%$.

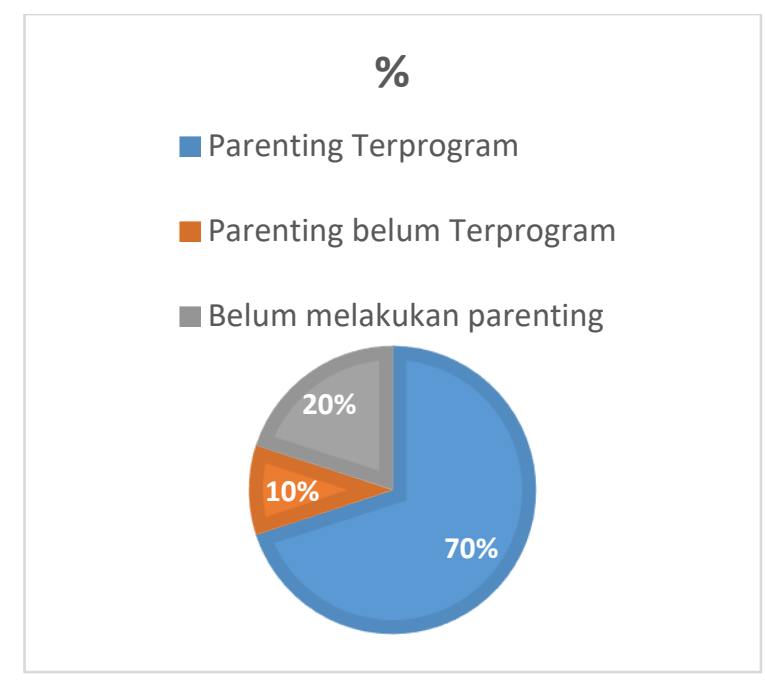

Gambar 2 Kondisi Pelaksanaan Parenting di RA

Beberapa RA menganggap parenting pada saat pandemi Covid-19 sama dengan kegiatan bimbingan anak belajar di rumah, sehingga RA melakukan kegiatan parenting bersamaan dengan kegiatan menginformasikan pembelajaran anak. Mereka menganggap informasi dan komunikasi kepada orang tua tentang 
kegiatan permainan hari itu sudah cukup mewakili kegiatan parenting.

Meski demikian, program parenting yang telah dijadwalkan dalam implementasinya juga bervariasi terlihat pada Gambar 3. Sebanyak 20\% RA melakukan parenting hanya di awal dan akhir tahun pembelajaran, 70\% RA melakukan secara rutin per tema atau terjadwal, sedangkan $10 \%$ sisanya RA melakukan kegiatan parenting secara tentatif atau sesuai kebutuhan.

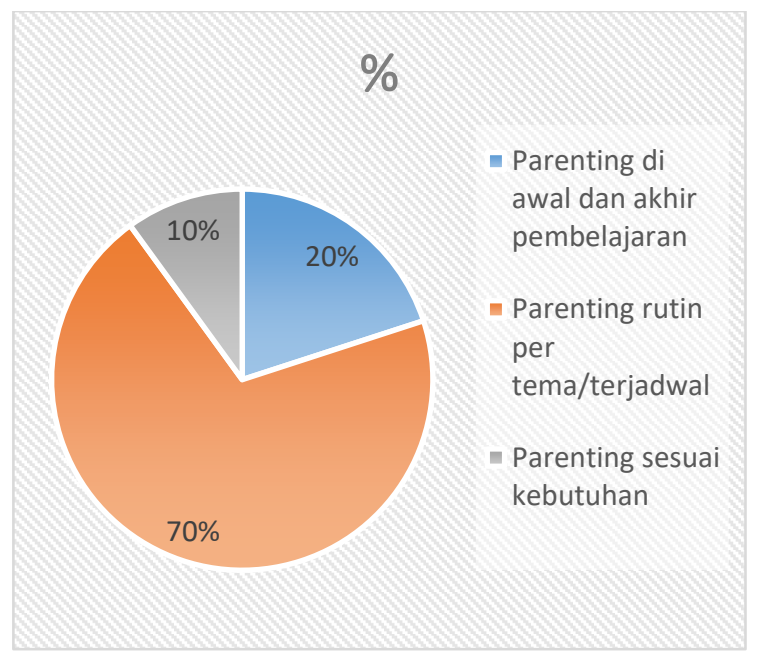

Gambar 3 Implementasi Parenting di RA

Terdapat beberapa faktor yang mendukung dan menghambat terlaksananya proses parenting di RA selama masa pandemi.

Faktor pendukung kegiatan parenting ini di antaranya adalah (1) pemahaman guru akan pentingnya kegiatan parenting di RA; (2) tertuangnya perencanaan pembelajaran secara sistematis sehingga program parenting dapat terealisir;

Keingintahuan yang besar dari orang tua dalam mengembangkan kemampuan kognitif anak.
Umumnya guru RA mengakui bahwa kegiatan parenting dapat dikatakan berhasil jika kerjasama dan program parenting telah dipahami urgensinya oleh pihak guru maupun orang tua. Selain itu, sistem pengadaan parenting itu betul-betul harus disosialisasikan agar orang tua yang sibuk atau bekerja tetap dapat mengikuti pelaksanaan parenting.

Sedangkan faktor penghambat terlaksananya parenting ditemukan dengan kondisi: (1) latar belakang pendidikan, pekerjaan dan status sosial orang tua; (2) tidak terprogramnya parenting; (3) parenting dilakukan jika ditemukan adanya masalah pada anak; dan (4) tidak maksimalnya akses media yang digunakan saat parenting melalui streaming online (seperti melalui zoom).

Melalui wawancara tertulis menggunakan Google Form, diketahui bahwa seluruh responden guru RA memahami pentingnya parenting bagi pendidikan anak usia dini. Dalam implementasinya tidak semua RA melaksanakan parenting secara terprogram dan sistematis, bahkan ada yang tidak melakukannya sama sekali.

Diperoleh data, bahwa faktor yang menjadi tantangan bagi guru RA dalam melakukan pembelajaran di masa pandemik ini adalah sebagian besar orang tua pada RA atau sebanyak $90 \%$ tidak memahami tentang program pencapaian pertumbuhan dan perkembangan anak usia dini, sedangkan hanya $10 \%$ sisanya orang tua yang sudah memahaminya. Padahal 
pemahaman orang tua akan pencapaian pertumbuhan dan perkembangan anak usia dini di masa pandemi menjadi sangat penting karena sebagian waktu bermain di sekolah dilakukan di rumah (belajar dari rumah).

Dari kebutuhan akan tercapainya pertumbuhan dan perkembangan anak yang optimal di masa pandemi, maka diperlukan kegiatan yang dapat menyampaikan informasi dan berkomunikasi tentang hal ini secara berkala, salah satunya adalah parenting berupa pertemuan antara guru, kepala RA dan orang tua.

Pengelolaan parenting dapat diinisiasi oleh pihak lembaga RA atau bahkan oleh orang tua dalam organisasi komite sekolah. Hal ini tentu saja memerlukan perencanaan di awal, sehingga saat pembentukan komite RA, program parenting ini sudah dijadikan agenda tersendiri.

Biasanya parenting dilakukan dengan mengangkat tema tertentu. Jika memang telah terjadwal dan memiliki anggaran tersendiri, maka lembaga RA dapat menghadirkan seorang pakar sebagai pembicara.

Belum banyak orang tua menyadari bahwa terdapat program pertumbuhan dan perkembangan anak usia dini yang harus dipantau dan diobservasi secara berkala. Seringkali saat guru RA hendak menghubungi orang tua, baik melalui Short Massages Service (SMS) maupun chatt WhatsApp, tidak langsung ditanggapi oleh orang tua, karena kesibukan mereka bekerja, atau sedang dalam perjalanan, dan lain-lain.

Parenting yang telah terealisasi dengan baik dapat meningkatkan kualitas pembelajaran anak RA akan lebih baik. Selain itu, manfaat kegiatan parenting yang dilakukan oleh RA dapat meningkatkan kedekatan guru dan orang tua, saling memberikan informasi dan saran, dan memperbaiki pola asuh yang dilakukan karena paradigma berpikir yang sama antara guru dan orang tua.

Melalui wawancara Zoom diketahui bahwa guru memerlukan suatu strategi atau media yang dapat meringankan tugas mereka memantau pertumbuhan dan perkembangan anak saat Belajar Dari Rumah (BDR) yang melibatkan orang tua.

Saat ini guru RA sudah menggunakan satu media sosial yang menjadi alat penghubung informasi dan komunikasi yaitu WhatsApp. Umumnya guru RA tidak terpikir untuk memanfaatkan media sosial lain seperti Facebook sebagai media dalam parenting. Padahal diperlukan suatu media komunikasi yang dapat memfasilitasi parenting berjalan lebih intensif dan fokus dalam membahas program pertumbuhan dan perkembangan, misalnya melalui kegiatan diskusi, menonton video, memberikan ilustrasi gambar, dan sebagainya tanpa harus scrolling atau melalui percakapan yang panjang seperti halnya dalam sebuah media sosial yang berisi chat seperti WhatsApp atau Telegram. 
Diketahui bahwa umumnya guru RA memiliki akun Facebook dan dapat mengelola akun tersebut, tetapi sebagian di antara mereka belum mengetahui bahwa akun Facebook-nya dapat dikelola menjadi suatu group yang dapat membentuk komunitas parenting. Sebagian lainnya sudah mengikuti berbagai pelatihan parenting dari komunitas parenting di media sosial, bahkan membagikannya kembali kepada orang tua sebagai konten parenting.

Pemanfaatan Facebook sebagai media parenting digunakan oleh guru RA sebanyak $10 \%$, menggunakan media sosial lain (whatsapp) sebanyak $10 \%$, dan $80 \%$ lainnya tidak menggunakan atau bahkan masih belum terpikir akan kebermanfaatan Facebook sebagai media parenting menurut Gambar 4.

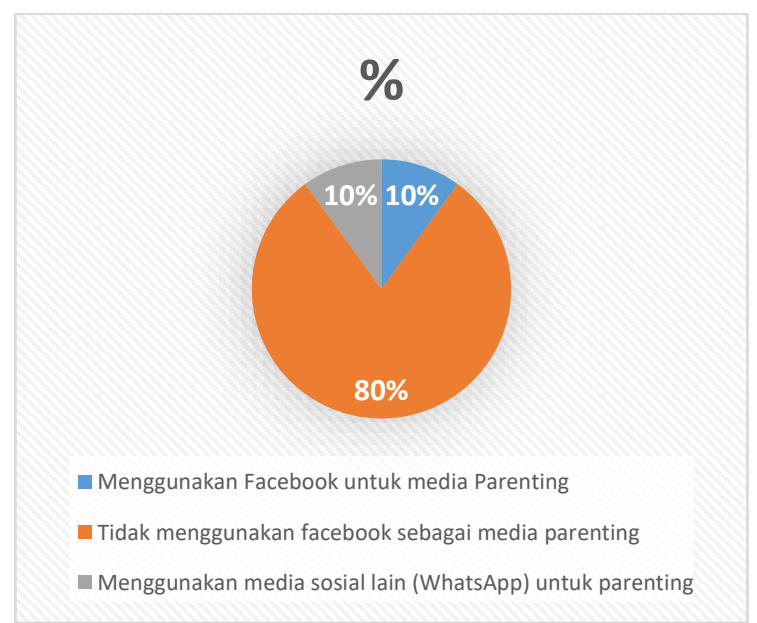

Gambar 4 Pemanfaatan Facebook sebagai Media Parenting

Hasil penemuan membuktikan bahwa guru RA sudah menyadari akan pentingnya parenting guna mengatasi kegagapan orang tua dalam program pertumbuhan dan perkembangan anak usia dini. Parenting dapat dimanfaatkan saat pendampingan anak belajar dari rumah. Akan tetapi, kondisi ini tidak didukung dengan belum dimanfaatkan sepenuhnya Facebook sebagai media parenting di lembaganya. Hal ini disebabkan guru RA menganggap Facebook hanya sekedar media sosial yang belum dikaitkan pada permasalahan yang mereka miliki dalam program parenting RA.

Salah satu layanan Facebook yaitu fasilitas untuk membuat grup yang berbeda dengan fanspage atau halaman. Tujuan grup di Facebook merupakan sebuah wadah komunitas di mana setiap anggota yang bergabung dalam grup tersebut memiliki interest atau ketertarikan terhadap topik yang sama.

Teknik membuat grup atau bergabung dalam sebuah grup pada Facebook sangat mudah. Diperlukan hadirnya seorang admin yang memiliki otoritas dalam membentuk grup, merekrut anggota dan mengelola grup hingga tercapai tujuan pembentukan grup tersebut. Selain itu, fasilitas grup Facebook yang dapat dimanfaatkan adalah memperoleh notifikasi aktivitas group, menampilkan posting penting di wall Facebook anggota, berkomunikasi dan berinteraksi sesama anggota, serta mengikuti aturan main yang dibuat dalam grup tersebut.

Fasilitas Facebook memberikan ruang untuk menulis dengan bebas, meng-upload foto, ataupun berkomentar. Sebuah grup Facebook 
yang memiliki tujuan tertentu, terdapat aturan atau tata krama yang harus disepakati dan dipatuhi sebelum anggota melakukan posting atau berkomentar, sesuai dengan kesepakatan bersama. Bisa saja aturan tersebut tertulis di dalam keterangan atau dokumen dalam grup (Kota, 2012).

Grup dalam Facebook tidak terlepas dari efektifitas admin sebagai pengelolanya. Grup bisa bersifat terbuka Maupun tertutup. Beberapa fitur dalam grup Facebook yang mendukung hal ini adalah pengelolaan keanggotaan, postingan terjadwal, log aktivitas, aturan grup, konten yang dilaporkan oleh anggota, pengaturan, peringatan moderasi maupun penilaian kualitas grup dari Facebook.

Dalam pengelolaan, pemanfaatan dan optimalisasi fitur grup Facebook, saat ini selain memposting informasi, foto dan video maupun berdiskusi, kini Facebook dapat memfasilitasi terhubungnya antar anggota melalui video konferensi. Admin dapat mengundang anggota, baik pilihan maupun umumnya untuk dapat mengikuti obrolan video ini.

Admin dapat membuat tagar topik pertemuan selanjutnya pada postingannya untuk dapat dipelajari oleh anggota dalam pertemuan berikutnya. Begitu pula dengan pengaturan acara mendatang yang dapat disesuaikan dengan kesepakatan anggota.

Salah satu keunikan grup Facebook ini adalah selain menyimpan foto dan video, beberapa file penting baik bentuknya Ms. Word, Ms. Powerpoint, maupun Ms. Excell. Bukan hanya admin, anggota juga dapat mengunggah dan mengunduh kembali isi bank file ini.

Fitur-fitur ini disimpan dalam sebuah ruang tersendiri sehingga para pengguna (user) dalam grup tidak perlu bersusah-susah naik melalui ratusan chat seperti media sosial lainnya.

Hasil penelitian ini memiliki makna pentingnya solusi kreatif dalam memecahkan permasalahan tidak maksimalnnya pendampingan orang tua terhadap anak RA yang disebabkan kurangnya pemahaman orang tua akan program pertumbuhan dan perkembangan anak usia dini.

Untuk itu, diperlukan tindak lanjut dalam mengoptimalisasikan Facebook sebagai salah satu media parenting. Teknik optimalisasi Facebook sebagai media parenting terbagi dua, secara umum maupun khusus.

Optimalisasi secara umum berupa: (1) mereview konsep parenting bagi guru RA dan menyesuaikan dengan kondisi RA masing-masing; menyusun jadwal parenting sesuai program pertumbuhan dan perkembangan anak usia dini di RA tersebut; (3) melibatkan orang tua dalam menentukan media sosial yang dapat dimanfaatkan sebagai alat komunikasi dan informasi yang efektif di masa pandemik sesuai dengan kondisi masing-masing lembaga sehingga jadwal parenting dapat 
terealisir; (4) membudayakan mencari solusi kreatif dengan mengadaptasi perkembangan teknologi dalam menyelesaikan permasalahan pembelajaran secara sistemik.

Secara khusus, upaya optimalisasi pemanfaatan Facebook sebagai media parenting yaitu dengan: (1) mengoptimalkan fitur-fitur yang terdapat dalam Facebook terutama pada pemanfaatan group Facebook; (2) guru bersama orang tua dalam komite misalnya bekerja sama membuat schedule tema, tayangan video atau materi dan ruang diskusi dalam group Facebook; (3) memberi penguatan dan tindak lanjut secara offline hasil diskusi parenting dengan menghubungkannya dengan pertumbuhan dan perkembangan anak sehari-hari, misalnya berupa laporan dan komunikasi timbal balik antara guru dan orang tua.

Optimalisasi pemanfaatan Facebook sebagai media parenting di RA dengan memanfaatkan fitur-fitur tertentu dalam Facebook, atau studi tentang efektifitas pertemuan terjadwal parenting dalam grup Facebook, atau bahkan mungkin terdapat impact yang lebih luas lagi seperti lahirnya komunitas parenting ayah dan pertemuan secara offline sebagai tindak lanjut dari parenting secara online, dan lain-lain.

\section{KESIMPULAN}

Umumnya Raudhatul Athfal belum memanfaatkan Facebook sebagai media parenting. Program parenting di RA pada masa pandemi Covid-19 berjalan dengan seadanya.

Diperlukan tindak lanjut penelitian ini berupa optimalisasi facebook sebagai media parenting. Teknik optimalisasi pemanfaatan facebook sebagai media parenting di RA bisa dilakukan melalui perbaikan pola kegiatan parenting sebagai pola umum, dan khususnya pemanfaatan fitur, konten dan tindak lanjut berupa parenting secara offline.

\section{DAFTAR PUSTAKA}

Anita Rahman, S. (2020). Penguatan Peran Orang Tua Dalam Mendapingi Pendidikan Anak Usia Dini Di Masa Pandemi Covid-19. Jurnal Golden Age, 4(02), 322-331. https:// doi.org/10.29408/jga.v4i02.2520

Fransiska. (2020). PERAN ORANG TUA DALAM KEGIATAN BELAJAR DI RUMAH PADA MASA PANDEMI COVID-19 ( Studi Kasus Pada Anak Usia 5-6 Tahun ). DUNIA ANAK: Jurnal Pendidikan Anak Usia Dini, 3(1).

Ismaniar, Utoyo,Setiyo. (2020). "Mirror of Effect" dalam Perkembangan Perilaku Anak pada Masa Pandemi Covid-19. DIKLUS: Jurnal Pendidikan Luar Sekolah, 2(September), 147-157.

Juliyani, A. (2020). Kemenag Bagikan Kuota Gratis Mulai Hari ini cek Siapa Saja yang Berhak Mendapatkannya. https:// bekasi.pikiran-rakyat.com/ pendidikan/pr- 
121045530/kemenag-bagikan-kuota-gratis-mulai-hari-ini-cek-siapa-saja-yangberhak-mendapatkannya

Kota, S. (2012). Apa itu Group di Facebook dan Aplikasi Fitur di dalamnya. Semarangkota.Com. http://semarangkota.com/04/apa-itu-group-Facebook/

Kurniati, E., Nur Alfaeni, D. K., \& Andriani, F. (2020). Analisis Peran Orang Tua dalam Mendampingi Anak di Masa Pandemi Covid-19. Jurnal Obsesi : Jurnal Pendidikan Anak Usia Dini, 5(1), 241. https:/ / doi.org/10.31004/obsesi.v5i1.541

Nirmala, B., \& Annuar, H. (2020). Home Visit: Strategi PAUD dari Rumah bagi Guru di Daerah 3T pada Masa Pandemi Covid-19. Jurnal Obsesi : Jurnal Pendidikan Anak Usia Dini, 5(2), 1052-1062. https:/ / doi.org/10.31004/obsesi.v5i2.716

Oktaria, R., \& Putra, P. (2020). Pendidikan Anak Dalam Keluarga Sebagai Strategi Pendidikan Anak Usia Dini Saat Pandemi Covid-19. Jurnal Ilmiah Pesona PAUD, 7(1), 41. https:/ / doi.org/10.24036/108806

Rohayani, F. (2020). Menjawab Problematika Yang Dihadapi Anak Usia Dini di Masa. Qawwam: Journal For Gender Mainstreaming, 14(1), 29-50. https://doi.org/10.20414/Qawwam.v14i1.2310

Tabi, A. (2020). Problematika Stay At Home Pada Anak Usia Dini Di Tengah Pandemi Covid 19. Jurnal Golden Age, 4(01), 190-200. https:/ / doi.org/10.29408/jga.v4i01.2244

Wardani, A., \& Ayriza, Y. (2020). Analisis Kendala Orang Tua dalam Mendampingi Anak Belajar di Rumah Pada Masa Pandemi Covid-19. Jurnal Obsesi: Jurnal Pendidikan Anak Usia Dini, 5(1), 772. https://doi.org/10.31004/obsesi.v5i1.705

Winarti, A. (2020). Implementasi Parenting pada Pendidikan Anak Usia Dini di Masa Pandemik Covid-19. Jurnal Pendidikan Pembelajaran Pemberdayaan Masyarakat, II(2), 131-145.

Wiresti, R. D. (2020). Analisis Dampak Work From Home pada Anak Usia Dini di Masa Pandemi Covid-19. Jurnal Obsesi: Jurnal Pendidikan Anak Usia Dini, 5(1), 641. https://doi.org/10.31004/obsesi.v5i1.563 